\title{
Quantification of mineral and toxic elements in milk of dairy cows by ICP-MS
}

\author{
Serap Kilıç Altun ${ }^{1}$, Nilgün Paksoy ${ }^{2}$ \\ ${ }^{1}$ Department of Food Hygiene and Technology, Faculty of Veterinary Medicine, Harran University, 63200, Şanluurfa/TURKEY \\ ${ }^{2}$ Department of Biochemistry, Faculty of Veterinary Medicine, Harran University, 63200, Şanlıurfa/TURKEY
}

Key Words:
cow milk
mineral
toxic element
ICP-MS


Received
$\begin{array}{ll}\text { Accepted } & : 21.01 .2021 \\ \text { Published Online }: 31.12 .2021 \\ \text { Article Code }: 866003\end{array}$

Correspondence:

N PAKSOY

(nilgunpaksoy@harran.edu.tr)

\begin{abstract}
Milk is an important component of mammalian metabolism which included micro and macronutrients. The objective of this study was to survey the concentrations of minerals and toxic elements in cow milk samples by inductively coupled plasma-mass spectrometry (ICP-MS). In this study, it was analyzed the content of sodium, magnesium, potassium, calcium, zinc, iron, copper, cobalt, manganese, nickel, selenium, chromium, titanium, arsenic, cadmium, lead, and thallium in cow milk samples $(n=25)$ collected from Kahramanmaraş province of Turkey. The highest levels recorded for potassium, calcium, and sodium with average concentrations of 1587.36, 1157.98, $643.34 \mathrm{mg} \mathrm{L}^{-1}$, respectively. The results revealed that the toxic element levels were below the limit of detection in cow milk samples. Regular element analysis of cow milk, which is the most widely used milk in dairy industry, is important for health.
\end{abstract}

ORCID

SK ALTUN :0000-0002-4203-2508

N PAKSOY :0000-0001-6231-5524

This research was presented as a oral presentation at the 1st International GAP Food, Agriculture and Veterinary Sciences Congress held in Sanliurfa on 29 November - 01 December 2019.

\section{INTRODUCTION}

Milk is an important requirement of mammalian metabolism, especially in the early stages of life. The reason why milk is important for mammalian metabolism is the presence of proteins, amino acids, fats and minerals necessary for metabolism. The minerals are in proportional equilibrium with ions, amino acids, carbohydrates, lipids (1), and these elements create the nutritional level of the milk. There are a lot of factors such as feed, geographical location, forage, maternal age, lactation stage, milking time, and environmental characteristics such as water, soil, affect the quality of milk $(1,2)$.

Minerals have biochemical, structural, and nutritional features in physical and mental metabolic reactions $(3,4)$. Sodium is a major cation for regulating osmotic pressure and acid-base balance (3). Potassium is important for nerve impulses and bone metabolism (3). Calcium is an essential element for bones, teeth, enzyme activation, and cardiac concentration (3, 5). Magnesium is important for muscle contraction and the regulation of blood pressure (3). When we examine the studies conducted in different regions of Turkey in the past years, Y1lmaz (2017) reported the most abundant minerals in cow's milk as calcium, magnesium, phosphorus and potassium from
Muş province (6). Also Dinç et al. (2019) reported that the most abundant minerals in cow milk as potassium, calcium and, phosphorus from Şanliurfa, Gaziantep and Mardin province (7).

The increase in environmental pollution leads to increased exposure of milking animals to environmental pollution and thus contamination of milk and dairy products. So, milk may include varied toxic elements such as thallium, cadmium, lead, arsenic. These toxic elements originated either geographical origin or pollution caused by developing technology (8-10). When the international studies are examined; heavy metal contamination in milk and dairy products, most notably lead and cadmium, has been reported $(3,7,11,12,13,14,15,16)$. However, these studies were done in the milk of cattle raised in the researchers' home countries and showed different results. Considering the studies conducted in our country, according to Temurci et al. (17) in the province of Ankara, Simşek et al. (18) in the province of Bursa, Ayar et al. (19) in the province of Konya, Bigucu et al. (20) in Çanakkale and İnci et al. (21) in Aydin reported the contamination of metals such as aluminum, arsenic, cadmium, chromium, cobalt, copper, iron, nickel, manganese, lead and selenium in milk and dairy products in their study. The objective of this study was to detect the 
mineral and toxic element concentrations in cow milk samples with inductively coupled plasma-mass spectrometry (ICP-MS).

\section{MATERIAL and METHODS}

\section{Sample Collection}

A number of 25 cow milk samples were gathered from Kahramanmaraş province of Turkey. Milk samples were collected between 8:00-10:00 am from different local market. Cow milk samples, collected in sterile polyethylene tubes and brought to the laboratory under the cold chain, stored at $-20^{\circ} \mathrm{C}$ until analysis. In this study, the method of Dinç et al.' study was modified and applied (7).

\section{Instrumentation}

Sodium, magnesium, potassium, calcium, zinc, iron, copper, cobalt, manganese, nickel, selenium, chromium, titanium, arsenic, cadmium, lead, and thallium were measured by ICP-MS (7700x, Agilent, The USA) with an AutoSampler (Cetac ASX520). A microwave dissolver (CEM Corporation, USA) with teflon vessels was used for sample digestion. The operating circumstances for microwave digestion were carried out in the order presented in Table 1. was calculated, respectively as shown in Table 2 .

Statistical Analysis

Minerals and toxic element concentrations were not ordinarily distributed; whence, a non-parametric test was used for the statistical analysis. Statistical significance was set at $\mathrm{P}<$ 0.05 and analyses were performed using software of SPSS 11.0 (IBM, USA).

\section{RESULTS}

Sodium, magnesium, potassium, calcium, zinc, iron, copper, nickel, selenium, and titanium were detected in all samples of cow milk (positive rate $100.0 \%$ ). Table 3 presents the mineral and toxic element concentrations measured in cow milk samples.

\section{DISCUSSION}

Minerals have a constitutional part in the mammalian structure and it is great familiar that milk and dairy products are well dietary resources of macro-minerals (sodium, magnesium, potassium, calcium). The quantity of minerals may vary in the function of the operated analytical methods, and therefore there is no complete contract within different

Table 1. Operating conditions of microwave digestion.

\begin{tabular}{cccc}
\hline Stage & Temperature $\left({ }^{\circ} \mathbf{C}\right)$ & Time (min.) & Power (Watt) \\
\hline 1 & 120 & 7 & 1600 \\
2 & 160 & 5 & 1600 \\
3 & 210 & 20 & 1600 \\
\hline
\end{tabular}

\section{Preparation and Digestion of Samples}

Five mL of milk samples were taken and put into the vessels of the microwave digestion. $4 \mathrm{~mL}$ of nitric acid $\left(\mathrm{HNO}_{3}\right)$ and 2 $\mathrm{mL}$ of hydrogen peroxide $\left(\mathrm{H}_{2} \mathrm{O}_{2}\right)$ was added and placed in the microwave digestion system. With an appropriate program, the milk samples were thawed in the microwave. The thawed samples were transferred to a sterile $50 \mathrm{~mL}$ falcon tube which was never used and diluted to $50 \mathrm{~mL}$ with ultra-pure water (7).

Macro, micro and toxic mineral levels of milk samples were measured by Agilent brand, 7500ce series ICP-MS (Tokyo, Japan) device in Mersin University Advanced Technology Education, Research and Application Center (MEITAM) laboratory (7).

\section{Quality Assurance}

On the ICP-MS device, each analysis was performed in 3 replicates and the average of these 3 replicates were taken. Analyses with a relative standard deviation (RSD\%) of these 3 replicates were repeated 3 . During the analyzes, a standard reading was performed in every 10 samples and the accuracy of the instrument was maintained until the end of the analysis. Limit of quantification (LOQ) and limit of detection (LOD) authors about mean content in milk and dairy products. The analytical method (ICP-MS) used in this study was preferred because it is sensitive, up-to-date and reliable considering the mineral and toxic metal contents of milk samples. The minerals are in chemical balance with amino acids, proteins, carbohydrates, and lipids present in higher amounts in milk (1). Magnesium plays an important role in approximately three hundred enzymatic reactions (7). The contents of magnesium in cow milk monitored in this study are higher than those reported in cow milk (151-167 $\left.\mathrm{mg} \mathrm{L}^{-1}\right)$ (22) and commercial milk samples from Spain $\left(126 \mathrm{mg} \mathrm{L}^{-1}\right)$ (23). This may be due to the vegetation the animal feeds on. Potassium is an intracellular cation that has a remarkable role for in heart, nervous, and urinary systems. The mean potassium level found in this study was $1587.3 \mathrm{mg} \mathrm{L}^{-1}$, which was higher than the results of Chi et al. (24) that was $1532 \mathrm{mg} \mathrm{L}^{-1}$ and lower than the findings of Bilandžić et al. (11) that was $2070 \mathrm{mg} \mathrm{L}^{-1}$. The level of iron in cow milk is higher than in the study of Park (25). Soil ingestion by grazing animals may notably influence the iron content of milk (26). Calcium is mandatory for nerve transmission, tooth 
Table 2. Detection limits and spike recovery of mineral and toxic elements in milk samples for quality control.

\begin{tabular}{|c|c|c|c|}
\hline Minerals and toxic elements & LOQ & LOD & Recovery (\%) \\
\hline $\mathrm{Na}\left(\mathrm{mg} \mathrm{L}^{-1}\right)$ & 24.0 & 2.0 & 101.1 \\
\hline $\operatorname{Mg}\left(\mathrm{mg} \mathrm{L}^{-1}\right)$ & 12.4 & 1.8 & 102.6 \\
\hline $\mathrm{K}\left(\mathrm{mg} \mathrm{L}^{-1}\right)$ & 8.2 & 1.6 & 101.9 \\
\hline $\mathrm{Ca}\left(\mathrm{mg} \mathrm{L}^{-1}\right)$ & 5.7 & 2.1 & 104.5 \\
\hline $\mathrm{Zn}\left(\mathrm{mg} \mathrm{L}^{-1}\right)$ & 10.6 & 3.4 & 102.6 \\
\hline $\mathrm{Fe}\left(\mathrm{mg} \mathrm{L}^{-1}\right)$ & 14.2 & 8.8 & 104.7 \\
\hline $\mathrm{Cu}\left(\mu \mathrm{g} \mathrm{L^{-1 }}\right)$ & 6.1 & 1.1 & 101.6 \\
\hline $\operatorname{Co}\left(\mu \mathrm{g} \mathrm{L}^{-1}\right)$ & 1.8 & 0.5 & 103.8 \\
\hline $\operatorname{Mn}\left(\mu g L^{-1}\right)$ & 11.2 & 1.9 & 104.2 \\
\hline $\mathrm{Ni}\left(\mu \mathrm{g} \mathrm{L}^{-1}\right)$ & 10.9 & 1.0 & 106.2 \\
\hline $\operatorname{Se}\left(\mu g \mathrm{~L}^{-1}\right)$ & 1.5 & 1.5 & 101.8 \\
\hline $\operatorname{Cr}\left(\mu g \mathrm{~L}^{-1}\right)$ & 0.7 & 0.5 & 104.2 \\
\hline $\operatorname{Ti}\left(\mu g L^{-1}\right)$ & 1.3 & 0.1 & 102.2 \\
\hline As $\left(\mu g \mathrm{~L}^{-1}\right)$ & 7.2 & 0.2 & 104.6 \\
\hline $\mathrm{Cd}\left(\mu \mathrm{g} \mathrm{L}^{-1}\right)$ & 8.1 & 0.7 & 105.1 \\
\hline $\mathrm{Pb}\left(\mu g \mathrm{~L}^{-1}\right)$ & 10.2 & 0.5 & 101.2 \\
\hline $\mathrm{Tl}\left(\mu \mathrm{g} \mathrm{L}^{-1}\right)$ & 10 & 1.5 & 100.9 \\
\hline
\end{tabular}


Table 3. Concentrations of minerals and toxic elements in cow milk samples.

\begin{tabular}{|c|c|c|c|c|}
\hline $\begin{array}{l}\text { Minerals and toxic ele- } \\
\text { ments }\end{array}$ & $\begin{array}{l}\text { Positive } \\
\text { sample no }\end{array}$ & Minimum & Maximum & Mean \pm SD \\
\hline $\mathrm{Na}\left(\mathrm{mg} \mathrm{L}^{-1}\right)$ & 25 & 241.5 & 807.9 & $643.3 \pm 166.4$ \\
\hline $\operatorname{Mg}\left(\mathrm{mg} \mathrm{L}^{-1}\right)$ & 25 & 67.9 & 148.3 & $103.4 \pm 21.1$ \\
\hline $\mathrm{K}\left(\mathrm{mg} \mathrm{L}^{-1}\right)$ & 25 & 1376.6 & 1708.3 & $1587.3 \pm 80.4$ \\
\hline $\mathrm{Ca}\left(\mathrm{mg} \mathrm{L}^{-1}\right)$ & 25 & 841.4 & 1447.9 & $1157.9 \pm 152.9$ \\
\hline $\mathrm{Zn}\left(\mathrm{mg} \mathrm{L}^{-1}\right)$ & 25 & 0.94 & 6.44 & $3.49 \pm 1.41$ \\
\hline $\mathrm{Fe}\left(\mathrm{mg} \mathrm{L}^{-1}\right)$ & 25 & 0.63 & 5.69 & $4.33 \pm 1.55$ \\
\hline $\mathrm{Cu}\left(\mu \mathrm{g} \mathrm{L}^{-1}\right)$ & 25 & 54.6 & 160.8 & $103.9 \pm 32.1$ \\
\hline $\operatorname{Co}\left(\mu \mathrm{g} \mathrm{L}^{-1}\right)$ & 4 & 13.06 & 16.04 & $14.07 \pm 1.34$ \\
\hline $\operatorname{Mn}\left(\mu g L^{-1}\right)$ & 4 & 22.26 & 37.38 & $29.3 \pm 7.59$ \\
\hline $\mathrm{Ni}\left(\mu \mathrm{g} \mathrm{L}^{-1}\right)$ & 25 & 81.5 & 618.5 & $279.1 \pm 144.8$ \\
\hline $\operatorname{Se}\left(\mu g \mathrm{~L}^{-1}\right)$ & 25 & 245.3 & 1545 & $975.9 \pm 387.2$ \\
\hline $\operatorname{Cr}\left(\mu g L^{-1}\right)$ & 11 & 60 & 315 & $182.7 \pm 85.2$ \\
\hline $\operatorname{Ti}\left(\mu g L^{-1}\right)$ & 25 & 2430 & 3998 & $3272 \pm 413.7$ \\
\hline As $\left(\mu g L^{-1}\right)$ & - & $<\mathrm{LOD}$ & $<\mathrm{LOD}$ & $<\mathrm{LOD}$ \\
\hline $\mathrm{Cd}\left(\mu \mathrm{g} \mathrm{L}^{-1}\right)$ & - & $<\mathrm{LOD}$ & $<\mathrm{LOD}$ & $<\mathrm{LOD}$ \\
\hline $\mathrm{Pb}\left(\mu \mathrm{g} \mathrm{L}^{-1}\right)$ & - & $<\mathrm{LOD}$ & $<\mathrm{LOD}$ & $<\mathrm{LOD}$ \\
\hline $\mathrm{Tl}\left(\mu \mathrm{g} \mathrm{L}^{-1}\right)$ & - & $<\mathrm{LOD}$ & $<\mathrm{LOD}$ & $<\mathrm{LOD}$ \\
\hline
\end{tabular}

formation, enzyme activity, and blood coagulation (24). The $\mathrm{L}^{-1}$, which was higher than the study from Mardin, Gaziantep, average calcium level in this study was estimated $1157.9 \mathrm{mg}$ and Şanlıurfa: $780.72,1014.12,766.78 \mathrm{mg} \mathrm{L}^{-1}$ (9). The levels 
of copper, zinc, and iron in cow milk samples were within the range of this literature $(3,4)$. The low concentrations of copper should be owing to zinc included in milk that steps in with the copper absorption system, describing the presence of a low concentration of this mineral in milk (27). The levels of arsenic, cadmium, lead, thallium in our study are below the detection limits and it is similar to the results of the study of Lante et al. (12). The findings of this study indicated that the studied cow milk samples usually, included an adequate quantity of minerals, a reality that has a major influence on its nutritional quality.

\section{CONCLUSION}

In this study, levels of 17 elements (sodium, magnesium, potassium, calcium, zinc, iron, copper, cobalt, manganese, nickel, selenium, chromium, titanium, arsenic, cadmium, lead, thallium) in cow milk from Kahramanmaraş province of Turkey were assessed where potassium, calcium, and sodium were found the highest in cow milk samples. Further studies are necessary to assess the levels of different elements in plenty of milk samples from various farms in Turkey for public health. Routinely conducting similar studies in different geographical regions in our country will be beneficial for the sustainability of the quality and safety of milk.

\section{DECLARATIONS}

\section{Ethics Approval}

This document does not require an ethics committe approval.

\section{Conflict of Interest}

Authors declare that there is no conflicts of interest for this study.

\section{Author Contribution}

All authors contributed to every step of the article.

\section{Data Availability}

The data that support the findings of this study are available from the corresponding author upon reasonable request.

\section{REFERENCES}

1. Singh M, Yadav P, Garg VK, Sharma A, Singh B, Sharma H. Quantification of minerals and trace elements in raw caprine milk using flame atomic absorption spectrophotometry and flame photometry. J Food Sci Technol. 2015; 52(8):5299-304. doi: 10.1007/s13197-014-1538-9.

2. Gallenberg LA, Vodicnik MJ. Transfer of persistent chemicals in milk. Drug Metab Rev. 1989; 21(2):277-317. doi: 10.3109/03602538909029943.

3. Zamberlin Š, Antunac N, Havranek J, Samaržija D. Mineral elements in milk and dairy products. Mljekarstvo. 2012; 62(2), 111-25.

4. Vahčić N, Hruškar M, Marković K, Banović M, Barić IC. Essential minerals in milk and their daily intake through milk consumption. Mljekarstvo. 2010; 60(2), 77-85.

5. Cashman KD. Macroelements, Nutritional Significance. In: Roginski, H., Fuquay, J.W., Fox, P.F. (eds.) Encyclopedia of Dairy Sciences, No 3. London: Academic Press; 2002. p.
2051-58.

6. Y1lmaz E. Sütlerin besinsel düzeylerinin karşılaştırılması (Doctoral dissertation, Adiyaman Üniversitesi). 2017.

7. Dinc H, Altun, SK, Paksoy N. Essential and Toxic Elements in Raw Cow Milk Collected from Sanluurfa, Gaziantep, and Mardin Provinces of Turkey. Fres. Environ. Bull. 2019; 28(4 A), 3073-78.

8. Rahimi E. Lead and cadmium concentrations in goat, cow, sheep, and buffalo milks from different regions of Iran. Food Chem. 2013; 136(2):389-91. doi: 10.1016/j.foodchem.2012.09.016.

9. Imperato M, Adamo P, Naimo D, Arienzo M, Stanzione D, Violante P. Spatial distribution of heavy metals in urban soils of Naples city (Italy). Environ Pollut. 2003; 124(2):247-56. doi: 10.1016/s0269-7491(02)00478-5.

10. Baize D, Sterckeman T. Of the necessity of knowledge of the natural pedo-geochemical background content in the evaluation of the contamination of soils by trace elements. Sci Total Environ. 2001; 264(1-2):127-39. doi: 10.1016/s00489697(00)00615-x.

11. Bilandžić N, Sedak M, Đokić M, Božić Đ, Vrbić A. Content of macro-and microelements and evaluation of the intake of different dairy products consumed in Croatia. J Food Compos Anal. 2015; 40, 143-37. https://doi.org/10.1016/j. jfca.2015.01.003.

12. Lante A, Lomolino G, Cagnin M, Spettoli P. Content and characterisation of minerals in milk and in crescenza and squacquerone Italian fresh cheeses by ICP-OES. Food Cont. 2006; 17, 229-33. https://doi.org/10.1016/j.foodcont.2004.10.010

13. Campillo N, Vinas P, Lopez-Garcia I, Hernandez-Cordoba M. Direct determination of copper and zinc in cow milk, human milk and infant formula samples using electrothermal atomization atomic absorption spectrometry. Talanta. 1998; 46, 615-622. https://doi.org/10.1016/S0039-9140(97)003068

14. Krachler M, Rossipal E, Irgolic Kj. Trace elements in formulas based on cow and soy milk and in Austrian cow milk determined by inductively coupled plasma mass spectrometry. Biol Trace Elem Res. 1998; 65, 53-57.

15. Bratakos MS, Lazos ES, Bratakos SM. Chromium content of selected Greek foods. Sci Total Environ. 2001; 290, 47-58. https://doi.org/10.1016/S0048-9697(01)01057-9

16. Licata P, Trombetta D, Cristanı M, Giofre F, Martıno D, Calo M, Naccar1 F. Levels of "toxic" and "essential" metals in samples of bovine milk from various dairy farms in Calabria, Italy. Environ Int. 2004; 30(1), 1-6. https://doi.org/10.1016/ S0160-4120(03)00139-9

17. Temurci H, Güner A. Ankara'da Tüketime Sunulan Süt ve Beyaz Peynirlerde Ağır Metal Kontaminasyonu. Atatürk Üniversitesi Vet. Bil. Derg. 2006; 1(1-2), 20-28.

18. Simsek O, Gultekın R, Oksuz O, Kurultay S. The effect 
of environmental pollution on the heavy metal content of raw milk. Nahrung-Food. 2000; 44, 360-371. https://doi.org/10 .1002/1521-3803(20001001)44:5<360::AID-FOOD360>3.0. $\mathrm{CO} ; 2-\mathrm{G}$

19. Ayar A, Sert D, Akın N. Konya'da tüketime sunulan süt ve ürünlerinin ağır metal içeriklerinin belirlenmesi. Selçuk Üniversitesi Ziraat Fakültesi Dergisi. 2007; 21(41), 58-64.

20. Bigucu E, Kaptan B, Palabiyık I, Oksuz O. The Effect of Environmental Factors on Heavy Metal and Mineral Compositions of Raw Milk and Water Samples. Journal of Tekirdag Agricultural Faculty. 2016; 13(04), 61-70.

21. Inci A, Aypak SÜ, Güven G. Aydın ilinde üretilen inek sütlerinde bazı ağır metal düzeylerinin araştırılması. Gıda. 2017; 42(3), 229-234.

22. Kondyli E, Katsiari MC, Voutsinas LP. Variations of vitamin and mineral contents in raw goat milk of the indigenous Greek breed during lactation. Food Chem. 2007; 100, 226-30. https://doi.org/10.1016/j.foodchem.2005.09.038.

23. Suarez-Luque S, Mato I, Huidobro JF, Simal-Lozano J. Determination of major metal cations in milk by capillary zone electrophoresis. Int Dairy J. 2007, 17, 896-901. https:// doi.org/10.1016/j.idairyj.2006.12.004.

24. Chi X, Zhang G, Yang Y, Hu F. Essential trace and toxic element levels in Tibetan yak's milk collected from Qinghai, China. Spect. Lett. 2016; 49(7), 477-81. https://doi.org/10.10 80/00387010.2014.924530.

25. Park YW. Comparison of mineral and cholesterol composition of different commercial goat milk products manufactured in USA. Small Rumin Res. 2000 Jul 1;37(1-2):115-24. doi: 10.1016/s0921-4488(99)00144-3.

26. Lopez-Alonso, M. Animal feed contamination by toxic metals. In: Fink-Gremmels J (ed) Animal feed contamination, effects on livestock and food safety. Woodhead Publishing, Cambridge; 2012. p. 183-201. https://doi.org/10.1533/9780 857093615.2.183.

27. Doull's C. I fondamenti dell'azione delle sostanze tossiche. 5th ed. Roma: EMSI; 2000. 